\title{
Environmental Implications of Municipal Dump Site on Soil Nitrogen in Calabar Metropolis, Nigeria
}

\author{
Victoria Francis Ediene \\ Linus Beba Akeh ${ }^{2}$ \\ Otobong Benjamin Iren ${ }^{1}$ \\ Sunday Marcus Afu ${ }^{1}$ \\ Ene Emmanuel Aki ${ }^{1}$ \\ Denis Michael Olim ${ }^{1}$
}

\author{
${ }^{1}$ Department of Soil ScienceUniversity of Calabar, Calabar, Nigeria \\ ${ }^{2}$ Department of Tourism StudiesUniversity of Calabar, Calabar, Nigeria \\ Corresponding author
}

DOI: https://doi.org/10.36941/mjss-2021-0o62

\begin{abstract}
Organic matter exhibit strong variations in nitrogen retention and transformation cycle in soil. However, nitrogen could be altered by seasonal variations, leading us to hypothesize that the open municipal waste dump site in Calabar exposed to dry and wet season could alter nitrogen dynamics in that soil. A total of sixty (6o) composite soil samples were collected at different landscape positions (summit crest, shoulder slope, toe slope, interfluve slope, valley floor) of a municipal dump site and a control (no refuse area) during the dry and wet seasons in Calabar and analyzed to ascertain the effects on forms and status of soil nitrogen. The soils were loamy sand across the study location with $\mathrm{pH}$ values of 4.50, 7.00, 6.70, 7.30, 5.00, 7.30 (dry season) and 5.00. 7.30, 7.00, 7.40, 5.90, 7.40 (wet season) for the control, summit crest, shoulder slope, toe slope, interfluve slope and valley floor accordingly. Values obtained for total nitrogen (N) from the study site were generally low (<0.21\%), with values for dry season slightly higher than the wet season. $\mathrm{NH}_{4}+$ recorded higher content in wet than in dry season with values ranging between $12.11-14.11 \mathrm{mg} / \mathrm{kg}$ (control), 14.6o-15.90 $\mathrm{mg} / \mathrm{kg}$ (Summit crest); 18.25 - $20.05 \mathrm{mg} / \mathrm{kg}$ (Shoulder slope), 18.30 - 20.20 mg/kg (Toe slope), 12.30 - 14.00 $\mathrm{mg} / \mathrm{kg}$ (Interfluve slope) and $9.24-11.07 \mathrm{mg} / \mathrm{kg}$ (Valley floor). The Shoulder and toe slopes recorded the highest $\mathrm{NH}_{4}+$ concentration in the wet season. No2- contents documented for the control site were within the ranges of 2.78- 3.20 and 3.22-3.62 mg/kg while the dumpsite had values between 2.49-3.45 and 2.98 -3.22 $\mathrm{mg} / \mathrm{kg}$ was observed for the shoulder position, the toe slope contained between 2.30-2.75 and 2.70 -2.82 $\mathrm{mg} / \mathrm{kg}$, the inter fluve slope had similar ranges of 2.32-2.90 and $2.70-3.08 \mathrm{mg} / \mathrm{kg}$, and the valley floor $2.45-$ 2.60 and $2.78-2.98 \mathrm{mg} / \mathrm{kg}$. No2-values were higher for the wet than dry season. NO3-nitrogen was observed to be excessive across the dumpsite with the highest values $>80 \mathrm{mg} / \mathrm{kg}$ obtained at the valley floor. The $\mathrm{NO}_{3}-$ values were higher in dry season across the all the landscape positions than in the wet season. The values were equally higher for the dumpsite than the control. It was observed that the dumpsite soils contend excessive $\mathrm{NO}_{3}$ - which could be converted to nitrous oxide ( $\left.\mathrm{N}_{2} \mathrm{O}\right)$ thus contributing to green house (GHG) emissions. It was also noted that seasonal variation did not significantly affect the $N$ content at the different landscape positions of the municipal dumpsite in Calabar. It is highly recommended that municipal waste be sorted and the organic materials composted to harness the rich $\mathrm{NO}_{3}$ - content as observed in this research.
\end{abstract}

Keywords: nitrogen distribution, dry and wet season, landscape positions, municipal dumpsite 


\section{Introduction}

Nitrogen $(\mathrm{N})$ is a vital element in crop production and ironically, often the most limiting nutrient in plant nutrition (Krivtsov et al 2011). This is partly attributed to the ease in which nitrate ( $\left.\mathrm{NO}_{3}\right)$ and $\mathrm{NH}_{4}+$ forms of nitrogen are removed from soil. Nitrate $\left(\mathrm{NO}_{3}\right)$ nitrogen is readily soluble in water thus being leached away under heavy rainfall or excessive irrigation, particularly in coarse textured soils while the $\mathrm{NH}_{4}+$ form is readily volatilized and fixed by clay and soil organic matter (Paul and Clark, 1989).

Organic materials of plant and animal origins exhibit strong variations in nitrogen content and contribute about $90 \%$ of soil's total nitrogen, thus playing a key role in the retention and transformation of N (Kelley and Stevenson 1995, Schulten and Schnitzer 1997). Nitrogen availability, is closely linked with the decomposition of organic matter, mineralization of organic nitrogen and the de-amination of the $\mathrm{N}$-containing amino acid and amino sugar (Chu $\mathrm{H}$, Grogan, 2010, Schimel and Bennett 2003). Soil organic matter though a key contributor to soil N, its decomposition process equally depletes significantly soil supplies of available $\mathrm{NH}_{4}+$ and $\mathrm{O}_{2}$ for use by micro-organisms thus becoming temporarily unavailable for plant uptake (Ferrari, 1999; Miller and Donahue, 1995). Some researchers have documented that nitrogen dynamics in soils is largely dependent on soil-plant interactions (Paul and Clark, 1989) while others are of the opinion that nitrogen content of the soil could also be altered by seasonal variations in precipitation/water content of the soil (Öquist et al., 2009; Ågren and Wetterstedt 2007). The changes in soil nitrogen forms and availability have also been attributed to other processes that portray a high level of heterogeneity. Morris and Boerner (1998) found land scape positions and variation in patterns of soil moisture to control soil nitrogen dynamics while Ferrari (1999) observed variability of $\mathrm{N}$ forms and status in soil to be associated with leaf litter. Municipal waste trends across the globe generally, have depicted high organic matter (50$90 \%$ ) contents (Asomani-Boateng and Haight, 1999) leaving us to hypothesize that it may alter the $\mathrm{N}$ content of soil.

In Calabar, municipal wastes from medical facilities, residential and commercial areas are collected from designated dumping locations within the metropolis and deposited in an open dump overlaying a large expanse of an undulating landscape in Ikot Effanga Mkpa (Fig 1). Wastes at the dump site are exposed to the prevalent climatic conditions and are intermittently subjected to open burning to decrease its bulkiness. This research aims at evaluating the seasonal variation in soil nitrogen forms and status on an undulating landscape along a municipal dump site in Calabar municipality.

\section{Materials and Methods}

\subsection{Location, climate and vegetation of the area}

This experiment was carried out on different landscape positions at the municipal dump site located in Ikot Effanga Mkpa, Calabar municipality of Cross River State in Nigeria (figure 1). The area is a municipal dumpsite used by Calabar Urban evelopment Authority (CUDA) for municipal waste disposal and maintained by the Environmental Sanitation Authority (ESA). The waste dump spans over an area of 2,355 sq $\mathrm{m}$. At the bottom of the slope is a stream where locals use for drinking and irrigation of their crops in dry season. The waste composition at the dump is not homogenous but a collection of different materials mainly domestic-household waste, hospital waste, industrial waste, faecal waste etc. with, organic waste fraction making up the largest proportion of it. The volume and composition of Calabar municipal waste is subject to seasonal variations. 


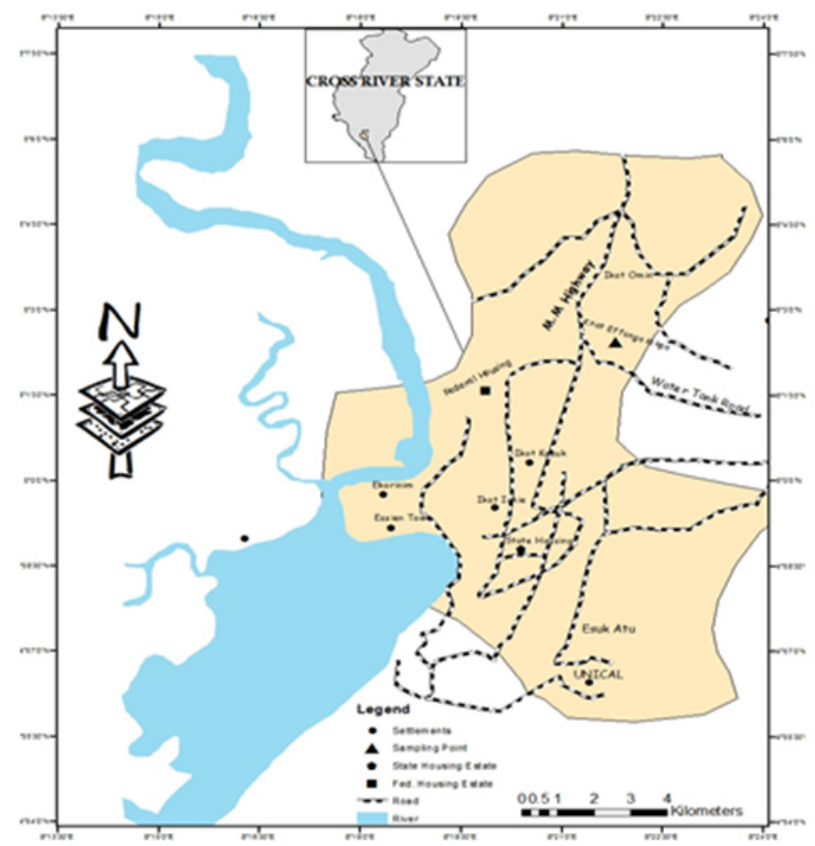

Figure 1: Map of the study area

Calabar lies between latitude 040 57" and 05005 " N and longitude 080 19" and 08025 "E. The study location falls within the lowland rainforest ecological zone with large areas of undisturbed forests (FAN, 2018). The study area is characterized with a mean annual rainfall of $2360 \mathrm{~mm}$ (range 2290$2680 \mathrm{~mm}$ ) and a bi-modal distribution pattern with peaks in June to July and September to October. In August, the rainy season is intercepted by a short dry spell referred to as "August Break". Calabar observes a distinct dry season of 3-4 months (December to March) and wet seasons of 8- 9 months (March to November) with high ambient temperature and relative humidity throughout the year. The mean daily minimum temperature ranges from 21 to 25 o $\mathrm{C}$ while the mean maximum temperature varies from 27 to 30 o $C$. The mean relative humidity is between $82-87 \%$ with tropical maritime winds of $60-70 \%$ (FAN, 2018). Calabar is a semi- industrial and residential area.

\subsection{Soil sampling procedure and preparation}

The sampling location consisted of an undulating landscape located within latitude 050 o2' $\mathrm{N}$ and longitude oo8o 21'E in Calabar. Sampling points were established along the different land scape positions.Global positioning system (GPS) (Etrex 20) was used to determine the latitude, longitude and elevation of each slope position. Samples taken from the opposite plot near to the dump site served as control.

Five composite soil samples from each of the five identified landscape positions (Summit crest, Shoulder slope, Toe slope, Interfluve slope, Valley floor) and a control site were collected at a depth of $0-45 \mathrm{~cm}$, with the aid of an auger. Eight samples were taken in each location and mixed thoroughly to represent a composite sample. A total of thirty ((30) composite samples were collected for each season (dry and wet) giving a total of 6o samples. Samples were collected in dry and wet seasons, representing dry and wet seasons, respectively. The soil samples collected were put in well labeled sampling bags and taken to the laboratory for analysis. The soil samples were air dried, ground, and passed through a 2-mm size sieve to remove materials greater than $2 \mathrm{~mm}$ in diameter. 


\subsection{Laboratory analysis}

The prepared soil samples were subjected to analysis using standard procedures as outlined by Udo et al. (2009). Particle size distribution: Particle size distribution was determined by the Bouyoucos hydrometer method using sodium hexametaphosphate as a dispersant.

Soil $\mathrm{pH}$ : The $\mathrm{pH}$ of the soil was determined in a 1:2.5 soil/distilled water suspension using a glass electrode $\mathrm{pH}$ meter (Model No 7020. Electronic instrument limited, Kent). Organic carbon: Soil organic carbon was determined by the Walkley and Black wet oxidation method.

\subsection{Forms of Nitrogen $(N)$}

Total nitrogen $(\mathrm{N})$ : This was determined by the modified macro-Kjeldahl digestion method of Black et al. (1965) as outlined by Udo et al. (2009).Ammonium nitrogen ( $\left.\mathrm{NH}_{4}\right)$ - N: This was determined by Richardson's (1938) method as outlined by Udo et al. (2009). Ten (10) grams of soil sample was weighed into $250-\mathrm{ml}$ shaker bottle then $100 \mathrm{ml}$ of $2 \mathrm{M} \mathrm{KCl}$ solution was added and shaken for I hour with the aid of a mechanical shaker. The supernatants were filtered using Whatman (No 42) filter papers. Five (5) $\mathrm{ml}$ of the extractant was used to develop the colour and readings were done at 636 nm using a spectrophotometer.

Nitrite (NO2)-N : From the same extract above, $10 \mathrm{~m} 1$ aliquot from each sample were pipetted into $50 \mathrm{ml}$ volumetric flask and Two (2) $\mathrm{ml}$ of $2 \mathrm{M} \mathrm{HC}_{1}$ added and made up-to $30 \mathrm{ml}$ with distilled water. Two milliliters ( $2 \mathrm{ml}$ ) Sulphanilic acid solution was also added, stirred and allowed to stand for 5 minutes. Alpha -naphthy lamine solution ( $10 \mathrm{ml}$ ) was added to the flask and made up to mark with distilled water. Five minutes was allowed for colour development. The absorbance was read at 520 nmand $\mathrm{NO}_{2}$ - N was extrapolated using standard curve concentration ( Udo et al., 2009) .

Nitrate $\left(\mathrm{NO}_{3}\right)$ : Thenitrate nitrogen was determined by weighing into the shaking bottles, $20 \mathrm{~g}$ of the experimental soil sample and $100 \mathrm{ml}$ solution of $0.25 \mathrm{M} \mathrm{K2So} 4$ was added and shaken for 30 minutes. The mixture was flittered through a Whatman No 42 filter paper. Colour was developed by Brucine Colorimetric method. $10 \mathrm{ml}$ aliquot of the experimental soil was transferred into $25 \mathrm{ml}$ volumetric flask and $10 \mathrm{ml}$ of concentrated $\mathrm{K}_{2} \mathrm{So}_{4}$ was rapidly added to $2 \mathrm{ml}$ of brucine reagent. It was mixed for 30 seconds and allowed to stand for 5 minutes 5 seconds. It was allowed to cool for 15 minutes and made up to mark with distilled water. The absorbance of the solution was read at 470 $\mathrm{nm}$. Using appropriate dilution factor the concentration of Nitrate was computed ( Udo et al., 2009).

\subsection{Statistical Analysis}

Descriptive analysis was used to calculate the variation between the different nitrogen compounds $\left(\mathrm{NH}_{4}\right)-\mathrm{N} ; \mathrm{NO}_{2}-\mathrm{N}$ and $\mathrm{NO}_{3}$ ) for dry and wetseasons on the different landscape positions of the dump site. Calculations were done using Statview statistics software.

\section{Results and Discussion}

Impact of seasonal variations and landscape position on particle size distribution of soil at the municipal waste dump site in Calabar

The sand contents in soils of the study sites were greater than $75 \%$, with silt $<19 \%$ and clay $<7$ $\%$ (Table 1 ) in both seasons irrespective of the landscape positions of the dump-site giving a loamy sand texture. The texture of the soils at the control site did not differ from that of the dumpsite for both in both dry and wet seasons.. The sandy nature of the soils is not unconnected with the sand stone parent material underlying the study area. 
Table 1: Mean physicochemical properties of the municipal waste dump site in Calabar for dry and wet seasons

\begin{tabular}{|c|c|c|c|c|c|c|c|}
\hline Parameters & Season & Control & Summit crest & Shoulder slope & Toe slope & Interfluve slope & Valley floor \\
\hline Latitude & & $05^{\circ} 02^{\prime} 09 \mathrm{~N}$ & $05^{\circ} \mathrm{O}{ }^{\prime} \mathrm{O} 3 \mathrm{~N}$ & $05^{\circ} 02^{\prime} 05 \mathrm{~N}$ & $05^{\circ} 02$ o8 N & $05^{\circ} 02 \mathrm{O} 2 \mathrm{~N}$ & $\overline{05^{\circ} \mathrm{O} 2^{\prime} \mathrm{O} 1 \mathrm{~N}}$ \\
\hline Longitude & & $008^{\circ} 21^{\prime}{ }_{51} \mathrm{E}$ & $008^{\circ} 21^{\prime} 54 \mathrm{E}$ & $008^{\circ} 21^{\prime} 5^{2 E}$ & $008^{\circ} 21^{\prime} 50 \mathrm{E}$ & $008^{\circ} 21^{\prime} 50 \mathrm{E}$ & $008^{\circ} 21^{\prime} 50 \mathrm{E}$ \\
\hline Attitude (m) & & 28.0 & 25.0 & 23.0 & 22.0 & 20.0 & 14.0 \\
\hline \multirow[t]{2}{*}{ Soil Temp. $\left({ }^{\circ} \mathrm{C}\right)$} & Dry & 30.0 & 39.0 & 39.0 & 38.0 & 36.0 & 29.0 \\
\hline & Wet & 33.0 & 35.0 & 33.0 & 32.0 & 32.0 & 27.0 \\
\hline \multirow[t]{2}{*}{ Sand $(\mathrm{g} / \mathrm{Kg})$} & Dry. & 79.0 & 78.0 & 78.0 & 77.0 & 87.0 & 75.0 \\
\hline & Wet & 78.0 & 78.0 & 78.0 & 77.0 & 88.0 & 76.0 \\
\hline \multirow[t]{2}{*}{ Silt (g/Kg) } & Dry. & 15.0 & 16.0 & 18.0 & 18.0 & 8.0 & 18.0 \\
\hline & Wet & 15.0 & 17.0 & 17.0 & 19.0 & 8.0 & 18.0 \\
\hline \multirow[t]{2}{*}{ Clay (g/Kg) } & Dry. & 6.0 & 6.0 & 4.0 & 5.0 & 5.0 & 7.0 \\
\hline & Wet & 7.0 & 5.0 . & 5.0 & 4.0 & 6.0 & 6.0 \\
\hline \multirow[t]{2}{*}{ Texture } & Dry. & LS & LS & LS & LS & LS & LS \\
\hline & Wet & LS & LS & LS & LS & LS & LS \\
\hline \multirow[t]{2}{*}{$\mathrm{pH}$} & Dry. & 5.6 & 7.0 & 6.7 & $7 \cdot 4$ & $5 \cdot 9$ & $7 \cdot 4$ \\
\hline & Wet & 5.0 & $7 \cdot 3$ & $7 \cdot 3$ & $7 \cdot 3$ & 5.0 & $7 \cdot 3$ \\
\hline \multirow{2}{*}{$\begin{array}{l}\text { Organic matter } \\
\quad(\%)\end{array}$} & Dry & 0.09 & 3.21 & $3 \cdot 31$ & 3.99 & 1.51 & 2.37 \\
\hline & Wet & 1.15 & 2.7 & 3.66 & 4.28 & 1.03 & 2.26 \\
\hline
\end{tabular}

Impact of seasonal variations and landscape position on soil $\mathrm{pH}$ and organic matter at the municipal waste dump site in Calabar

The soils at the study location during the dry season had mean $\mathrm{pH}$ values ranging from 5.6--7.4 while during the wet season (wet season) the values ranged from $5.0-7.3$. The lowest $\mathrm{pH}$ values were recorded in control soils in both seasons and were strongly acid in reaction, while soils at the different landscape positions of the dump site were slightly acid to very slightly alkaline with highest values obtained at Toe slope and Valley floor (Table 1). The strongly acid $\mathrm{pH}$ observed for the control soil is typical of the soils in Calabar (Ediene et al., 2016). Lower $\mathrm{pH}$ values were observed during the wet season across the different landscape positions when compared with values obtained during the dry season. The seasonal differences in $\mathrm{pH}$ could be attributed to the moisture regime tenable in the study location characterized by high rainfall in the wet season and also to the sandy nature of these soils which enhanced the leaching of basic cations across the different locations.

The increased $\mathrm{pH}$ observed in dry and rainy seasons at the dump site over the control could be attributed to the various stages of decomposition of the different organic material deposit. The $\mathrm{pH}$ values observed for the dump-site were in line with the 5.4 - 7.0 value range documented by Hargety et al. (1973) and 5.0 - 8.5 or less by Pavoni et al. (1975) for organic matter at different stages of decomposition in aerobic conditions. These suggest that the slightly acid to very slightly Alkaline observed for the dump-site is influenced by decomposition of organic wastes.

Results for the organic matter content of the studied soils were quite revealing. For the wet season, soils at the control site were medium (1.0 -1.5 \%) in organic matter while the dumpsite positions were very high in organic matter (>2.0 \%) with the Toe slope recording the highest (3.99 $\%)$ content. The interfluve slope position was however, medium in OM content for both seasons. This is not unconnected with the fact that the position was by the entrace to the dumpsite as such did not have much waste deposits. Generally, organic matter contents were higher in the various landscape positions of the dump-site in both seasons (dry and wet) with the highest recorded during the rainy season when compared with the control across the study sites. The high organic matter content observed for the dump-site could be attributed to the high quantities of organic materials deposited and the high amount of moisture resulting in a slow rate of decomposition.

Effects of seasonal variations and landscape position on forms of soil nitrogen at the municipal waste dump site in Calabar 


\subsection{Total Nitrogen $(N)$}

The mean values of total nitrogen in the soil during the dry season ranged from $0.05-0.30 \%$ with the lowest value obtained in the control and the highest at the Toe slope position while values ranged from $0.01-0.20 \%$ in wet season (Fig 2). The lowest total nitrogen value in the soil during the wet season was at the interfluve slope position while the highest content was from the Toe slope position of the dump site. Coefficient of variation values of .0.1964\%, $0.1065 \%, 0.0784 \%, 0.2191 \%, 0.7536 \%$ and $0.2512 \%$ ( Table 2) were recorded for total nitrogen content of the soils at the control, summit crest, shoulder slope, toe slope, interfluve slope and valley floor positions correspondingly. The highest nitrogen content for both seasons were recorded at the toe slope (Fig. 2).

Total nitrogen in a given soil measures the organic and inorganic $\mathrm{N}$ content of that soil. This is because about 98 percent of the soil nitrogen is stabilized in organic matter as reported by Bationo et al. (2003).Soil $\mathrm{N}$ content is reported to increase as soil moisture increases (Paul and Clark, 1989), however, the soil of the study area was loamy sand with a reputed low water holding capacity which could account for the low $\mathrm{N}$ mineralization. The $\mathrm{N}$ values obtained were within the range reported for soils in Calabar by Akpan-Idiok (2012).

The values for total nitrogen were slightly higher in dry season than in wet season (Fig 2). Despite the high organic matter deposit in the dump site, the percentage nitrogen content in these soils were low (< o.2) following the rating of Landon (1991). The low nitrogen contents observed across the different sampling points during the dry and wet seasons could be as a result of organic matter decomposition which requires high amounts of inorganic nitrogen $(\mathrm{N})$ and oxygen (O2) (Ferrari, 1999). It could also be due to hydrolysis and fermentation of nitrogenous fractions of biodegradable refuse substrates of which ammonium nitrogen represents the major proportion of total nitrogen.

\subsection{Ammonium nitrogen $\left(\mathrm{NH}_{4}+-\mathrm{N}\right)$}

The values for $\mathrm{NH}_{4}+$ in soils of the study area ranged between $11.44-13.38$ and $12.11-14.11 \mathrm{mg} / \mathrm{kg}$ (control); $14.91-15.88$ and $14.60-15.90 \mathrm{mg} / \mathrm{kg}$ (Summit crest); $18.43-19.38,18.25-20.05 \mathrm{mg} / \mathrm{kg}$ (Shoulder slope); 12.40 - 13.42, 18.30 - $20.20 \mathrm{mg} / \mathrm{kg}$ (Toe slope); $8.20-9.05$ and $12.30-14.00 \mathrm{mg} / \mathrm{kg}$ (Interfluve slope) and 7.90 - 9.59 and $9.24-11.07 \mathrm{mg} / \mathrm{kg}$ (Valley floor) for dry and wet seasons respectively. The means for the control, summit crest, shoulder slope, toe slope, interfluve slope and valley floor toposequences had coefficient variabilities of $0.06 \%$,

Table 2: Descriptive statistics for Total Nitrogen $(\mathrm{N})$ in soil on different landscapes positions of an open municipal dump site in Calabar for dry and wet seasons

\begin{tabular}{lrrrrrr}
$\begin{array}{l}\text { Descriptive } \\
\text { Statistics }\end{array}$ & Control & Summit & Shoulder & Toe slope & Interfluve slope & Valley floor \\
\hline Mean & .0550 & .1400 & .1700 & .2500 & .0300 & .0900 \\
Std. Dev. & .0108 & .0149 & .0133 & .0548 & .0226 & .0226 \\
Std. Error & .0034 & .0047 & .0042 & .0173 & .0071 & .0071 \\
Count & 10 & 10 & 10 & 10 & 10 & 10 \\
Minimum & .0400 & .1200 & .1500 & .1800 & .0100 & .0600 \\
Maximum & .0700 & .1700 & .1900 & .3200 & .0600 & .1200 \\
\# Missing & 0 & 0 & 0 & 0 & 0 & 0 \\
Variance & .0001 & .0002 & .0002 & .0030 & .0005 & .0005 \\
Coef. Var. & .1964 & .1065 & .0784 & .2191 & .7536 & .2512 \\
Range & .0300 & .0500 & .0400 & .1400 & .0500 & .0600 \\
Sum & .5500 & 1.4000 & 1.7000 & 2.5000 & .3000 & .9000 \\
Sum Squares & .0313 & .1980 & .2906 & .6520 & .0136 & .0856 \\
Geom. Mean & .0540 & .1393 & .1695 & .2445 & .0220 & .0873 \\
Harm. Mean & .0530 & .1386 & .1690 & .2391 & .0165 & .0846 \\
Skew ness & $-1.023 \mathrm{E}-15$ & .4243 & -.2965 & $3.864 \mathrm{E}-17$ & .3041 & -.1216 \\
Kurtosis & -1.1293 & .1000 & -.9687 & -1.7218 & -1.7051 & -1.5350 \\
Median & .0550 & .1400 & .1700 & .2500 & .0200 & .0900 \\
IQR & .0100 & .0200 & .0200 & .1000 & .0400 & .0400 \\
Mode &. & .1400 &. &. & .0100 & .1100 \\
10\% Tr. Mean & .0550 & .1388 & .1700 & .2500 & .0288 & .0900 \\
MAD & .0050 & .0100 & .0100 & .0500 & .0100 & .0200 \\
\hline & & & & & & \\
\hline
\end{tabular}




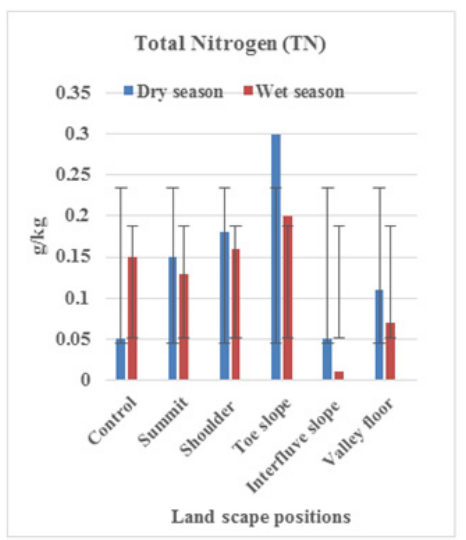

Figure 2: Mean seasonal variation of Total Nitrogen $(\mathrm{N})$ in soils on different landscapes positions of an open municipal dump site in Calabar

Table 3: Descriptive statistics for $\mathrm{NH}_{4}+-$ Nin soil on different landscapes positions of an open municipal dump site in Calabar for dry and wet seasons

\begin{tabular}{lrrrrrr}
$\begin{array}{l}\text { Descriptive } \\
\text { Statistics }\end{array}$ & Control & Summit & Shoulder & Toe slope & Interfluve slope & Valley floor \\
\hline Mean & 12.765 & 15.065 & 18.840 & 15.866 & 10.700 & 9.530 \\
Std. Dev. & .849 & .583 & .770 & 3.716 & 2.669 & .900 \\
Std. Error & .268 & .185 & .243 & 1.175 & .844 & .285 \\
Count & 10 & 10 & 10 & 10 & 10 & 10 \\
Mnimum & 11.440 & 13.930 & 17.460 & 11.440 & 7.400 & 7.900 \\
Maximum & 14.110 & 15.900 & 20.050 & 20.200 & 14.000 & 11.070 \\
\# Missing & 0 & 0 & 0 & 0 & 0 & 0 \\
Variance & .721 & .340 & .592 & 13.811 & 7.126 & .810 \\
Coef. Var. & .066 & .039 & .041 & .234 & .249 & .094 \\
Range & 2.670 & 1.970 & 2.590 & 8.760 & 6.600 & 3.170 \\
Sum & 127.650 & 150.650 & 188.400 & 158.660 & 107.000 & 95.300 \\
Sum Squares & 1635.937 & 2272.606 & 3554.786 & 2641.603 & 1209.035 & 915.499 \\
Geom. Mean & 12.740 & 15.055 & 18.826 & 15.470 & 10.397 & 9.491 \\
Harm. Mean & 12.715 & 15.044 & 18.811 & 15.082 & 10.101 & 9.452 \\
Skew ness & .336 & -.253 & -.150 & .031 & .063 & -.052 \\
Kurtosis & -.839 & -.185 & -.753 & -1.843 & -1.750 & -.453 \\
Median & 12.430 & 14.985 & 18.730 & 15.860 & 10.675 & 9.415 \\
IQR & 1.050 & .440 & 1.030 & 7.200 & 4.750 & 1.210 \\
Mode & 12.430 & 15.300 &. & 12.400 &. &. \\
10\% Tr. Mean & 12.762 & 15.102 & 18.861 & 15.878 & 10.700 & 9.541 \\
MAD & .445 & .315 & .565 & 3.460 & 2.375 & .550 \\
\hline
\end{tabular}

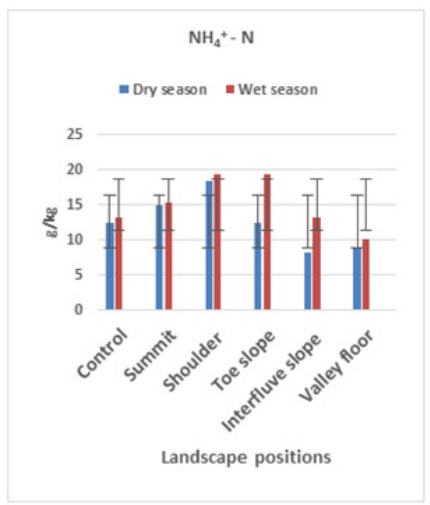

Figure 3: Mean seasonal variation of $\mathrm{NH}_{4}+-\mathrm{N}$ in soils on different landscapes positions of an open municipal dump site in Calabar 
Results in Table 3 indicate $0.03 \%, 0.04 \%, 0.2 \%, 0.2 \%$ and $0.09 \%$ accordingly. Ammonium content was higher during wet season than in dry season. The Shoulder and toe slopes had the highest concentration of $\mathrm{NH}_{4+}$ in wet season while the lowest concentration was observed on the valley floor (Fig 3). $\mathrm{NH}_{4+-} \mathrm{N}$ does not accumulate in soil owing to soil moisture and temperature regimes which enables the easy conversion of $\mathrm{NH}_{4}+$ to $\mathrm{NO}_{2}$ - and then $\mathrm{NO}_{3}-$. This is because any ecosystem alteration that increases soil $\mathrm{NH}_{4}+$ availability usually accelerates nitrification.

The values obtained for $\mathrm{NH}_{4+-} \mathrm{N}$ in dry and wet seasons from the different landscape positions were relatively high, above the ammonium nitrogen typical concentrations of $2-10 \mathrm{mg} / \mathrm{kg}$ for soils as documented by Marx et al. (1999). This could be due to the assertion that the concentration of ammonia nitrogen increases with the increase in age of the dump-site (Korniawan et al., 2006). These high levels of ammonium nitrogen could be toxic to soil organisms.

$\mathrm{NH}_{4+-} \mathrm{N}$ is ranked a major toxicant to living organisms, and has been validated by various toxicity analyses using bioassays and various bio-indicators such as Salmo gairdnieri and Oncorhynchus nerka (Korniawan et al., 2006). Higher concentrations of $\mathrm{NH}_{4+-} \mathrm{N}$ have also been documented to enhance algal growth (as was visibly observed at the toe slope and valley floor) and promote eutrophication due to decreased dissolved oxygen (Deng and Englehardt, 2007).

\subsection{Nitrite nitrogen $\left(\mathrm{NO}_{2}-\mathrm{N}\right)$}

Values for $\mathrm{NO}_{2}$ - obtained from the control plot were within the ranges of $2.78-3.20$ and $3.22-3.62$ $\mathrm{mg} / \mathrm{kg}, 2.49-3.45$ and $2.98-3.22 \mathrm{mg} / \mathrm{kg}$ was documented for the shoulder, the toe slope contained between $2.30-2.75$ and $2.70-2.82 \mathrm{mg} / \mathrm{kg}$, the inter fluve slope had similar ranges of $2.32-2.90$ and 2.70 $-3.08 \mathrm{mg} / \mathrm{kg}$, and the valley floor $2.45-2.60$ and $2.78-2.98 \mathrm{mg} / \mathrm{kg}$ for the dry and wet seasons in the given order. Standard deviations of $0.26,0.26,0.24,0.17,0.24,0.18$ were recorded for the means of the control, summit crest, shoulder slope, toe slope, interfluve slope and valley floor indicating that the means for dry seasondid not differ from that of the wet season. The means were negatively skewed except for the control (Table 4).

The NO2- values obtained for the dump site were lower than the values from the control for both seasons (Fig 4). The NO2- values were generally lower than values obtained for other forms of nitrogen. This could be attributed to the rapid oxidation of $\mathrm{NO}_{2}-$ to $\mathrm{NO}_{3}-$ - in soil when formed. Paul and Clark (1989), noted that nitrite ( $\left.\mathrm{NO}_{2}-\right)$ is rapidly oxidized in soil at temperatures between $400 \mathrm{C}$ to $600 \mathrm{C}$. This phenomenon is actually fortunate because nitrite nitrogen is toxic to living organisms (Miller and Donahue 1995).The results observed in this study has confirmed reports by these authors however, the soil temperatures reported by Paul and Clark, (1989) were substantially higher than the temperature that was observed at the dump site as recoreded in Table 1.

\subsection{Nitrate nitrogen $\left(\mathrm{NO}_{3}-\mathrm{N}\right)$}

Nitrate ( $\left.\mathrm{NO}_{3}-\right)$ nitrogen had values ranging from $58.20-62.10$ and $57.36-59.40 \mathrm{mg} / \mathrm{kg}$ for the control; 52.80 - 55.46 and 48.79 - $50.86 \mathrm{mg} / \mathrm{kg} ; 57.04-59.22$ and $54.80-56.50 \mathrm{mg} / \mathrm{kg} ; 52.06-56.00$ and 50.26 - $54.00 \mathrm{mg} / \mathrm{kg} ; 50.80-68.86$ and 56.06 - $57.60 \mathrm{mg} / \mathrm{kg} ; 75.20-84.40$ and $71.22-79.00 \mathrm{mg} / \mathrm{kg}$ for the summit crest, shoulder slope, toe slope, interfluve slope and valley floor, for the dry and wet seasons sequentially. The means had coefficient of variations of $0.02 \%, 0.05$. 
Table 4: Descriptive statistics for $\mathrm{NO}_{2}-\mathrm{N}$ in soil on different landscapes positions of an open municipal dump site in Calabar for dry and wet seasons.

\begin{tabular}{lrrrrrr} 
Descriptive & & & & & & \\
Statistics & Control & Summit & Shoulder & Toe slope & Interfluve slope & Valley floor \\
\hline Mean & 3.210 & 2.610 & 3.035 & 2.705 & 2.750 & 2.715 \\
Std. Dev. & .265 & .266 & .248 & .174 & .243 & .188 \\
Std. Error & .084 & .084 & .078 & .055 & .077 & .059 \\
Count & 10 & 10 & 10 & 10 & 10 & 10 \\
Minimum & 2.780 & 2.140 & 2.490 & 2.300 & 2.320 & 2.450 \\
Maximum & 3.620 & 2.950 & 3.450 & 2.950 & 3.080 & 2.980 \\
\# Missing & 0 & 0 & 0 & 0 & 0 & 0 \\
Variance & .070 & .071 & .062 & .030 & .059 & .035 \\
Coef. Var. & .083 & .102 & .082 & .064 & .089 & .069 \\
Range & .840 & .810 & .960 & .650 & .760 & .530 \\
Sum & 32.100 & 26.100 & 30.350 & 27.050 & 27.500 & 27.150 \\
Sum Squares & 103.673 & 68.756 & 92.666 & 73.443 & 76.158 & 74.030 \\
Geom. Mean & 3.200 & 2.597 & 3.025 & 2.700 & 2.740 & 2.709 \\
Harm. Mean & 3.190 & 2.584 & 3.016 & 2.694 & 2.729 & 2.703 \\
Skew ness & .030 & -.533 & -.619 & -1.184 & -.567 & -.037 \\
Kurtosis & -1.031 & -.920 & .912 & 1.210 & -.715 & -1.487 \\
Median & 3.210 & 2.685 & 3.000 & 2.750 & 2.800 & 2.715 \\
IQR & .460 & .400 & .230 & .070 & .270 & .330 \\
Mode & 3.000 &. & 3.000 &. & 2.800 &. \\
10\% Tr. Mean & 3.212 & 2.626 & 3.051 & 2.725 & 2.762 & 2.715 \\
MAD & .210 & .160 & .080 & .050 & .135 & .165 \\
\hline
\end{tabular}

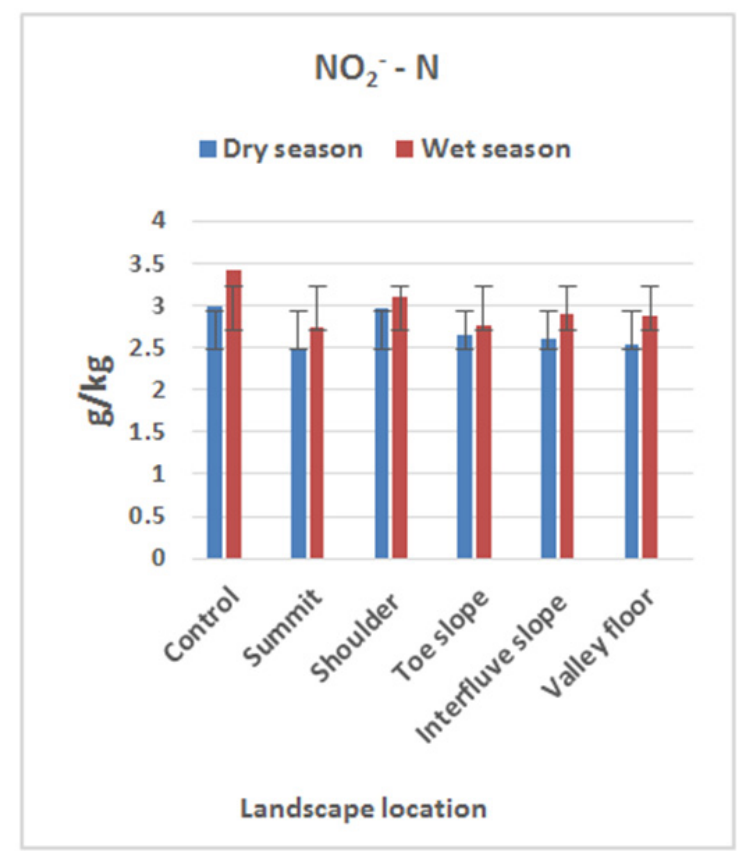

Figure 4: Mean seasonal variation of $\mathrm{NO}_{2}-{ }_{-} \mathrm{N}$ in soils on different landscapes positions of an open municipal dump site in Calabar 
Table 5: Descriptive statistics for $\mathrm{NO}_{3}-\mathrm{N}$ in soil on different landscapes positions of an open municipal dump site in Calabar for dry and wet seasons.

\begin{tabular}{lrrrrrr} 
Descriptive & Control & Summit & Shoulder & Toe slope & Interfluve slope & Valley floor \\
Statistics & 59.190 & 52.105 & 56.920 & 53.090 & 58.330 & 78.655 \\
\hline Mean & 1.477 & 2.599 & 1.424 & 1.728 & 4.568 & 3.760 \\
Std. Dev. & .467 & .822 & .450 & .547 & 1.445 & 1.189 \\
Std. Error & 10 & 10 & 10 & 10 & 10 & 10 \\
Count & 57.360 & 48.790 & 54.800 & 50.260 & 50.800 & 71.220 \\
Minimum & 62.100 & 55.460 & 59.220 & 56.000 & 68.860 & 84.400 \\
Maximum & 0 & 0 & 0 & 0 & 0 & 0 \\
\# Missing & 2.183 & 6.756 & 2.028 & 2.987 & 20.871 & 14.136 \\
Variance & .025 & .050 & .025 & .033 & .078 & .048 \\
Coef. Var. & 4.740 & 6.670 & 4.420 & 5.740 & 18.060 & 13.180 \\
Range & 591.900 & 521.050 & 569.200 & 530.900 & 583.300 & 786.550 \\
Sum & 35054.204 & 27210.115 & 32417.117 & 28212.364 & 34211.724 & 61993.317 \\
Sum Squares & 59.174 & 52.047 & 56.904 & 53.065 & 58.174 & 78.573 \\
Geom. Mean & 59.157 & 51.989 & 56.888 & 53.039 & 58.024 & 78.490 \\
Harm. Mean & .770 & .098 & .126 & .071 & .890 & -.376 \\
Skew ness & -.465 & -1.661 & -1.207 & -.751 & 1.416 & -.101 \\
Kurtosis & 58.740 & 51.830 & 56.770 & 53.045 & 57.550 & 78.500 \\
Median & 1.800 & 4.730 & 2.340 & 1.940 & 3.840 & 2.970 \\
IQR & 58.200 &. &. & 54.000 &. & 78.000 \\
Mode & 59.055 & 52.100 & 56.898 & 53.080 & 57.955 & 78.866 \\
10\% Tr. Mean & .620 & 2.195 & 1.150 & .970 & 1.780 & 1.650 \\
MAD & & & & & &
\end{tabular}

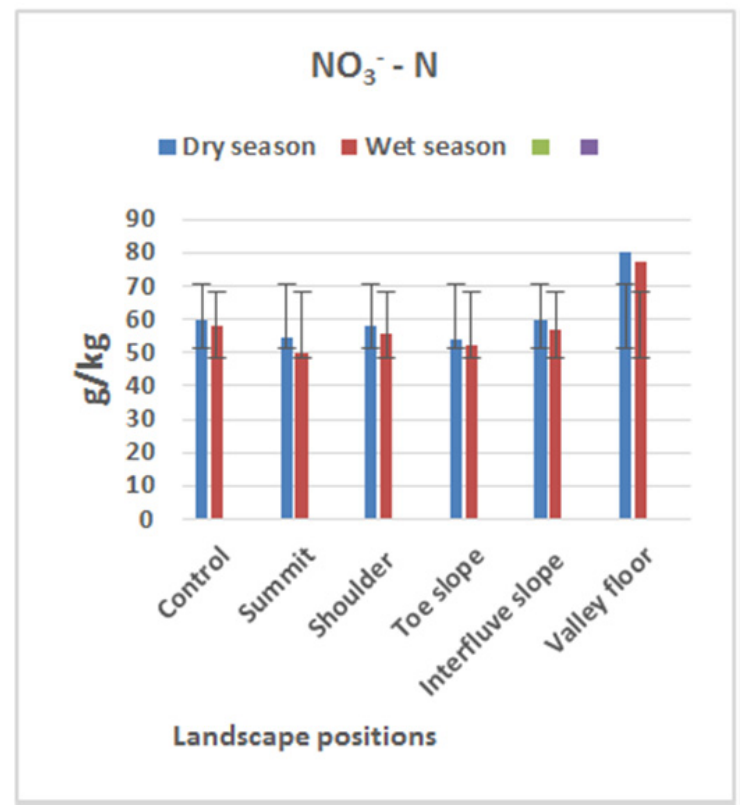

Figure 5: Mean seasonal variation of $\mathrm{NO}_{3}{ }^{-}-\mathrm{N}$ in soils on different landscapes positions of an open municipal dump site in Calabar 
Percentage representation for the control was $0.02 \%, 0.03 \%, 0.07 \%$ and $0.04 \%$ at the different topo-positions accordingly. The data were positively skewed (Table 5). The valley floor recorded the highest content of $\mathrm{NO}_{3}{ }^{-}-\mathrm{N}$ (Fig 5). Despite the high rate of leaching and solubilization of $\mathrm{NO}_{3}^{-}$, its content in the study soils were excessive $(>30 \mathrm{mg} / \mathrm{kg})$. Nitrate has been reported to be high in soils, marine environments and manure piles and during sewage processing (Hirobe et al., 2003). Nitrate is reported to be deficient in soils with low $\mathrm{pH}(<5.5)$ such as soils in the study area, this is because of reduced nitrification.

However, organic matter (organic waste) is an important source of $\mathrm{NO}_{3}$ - and nitrate accumulation may correlate with organic matter deposits patterns across landscapes. These excessive values of $\mathrm{NO}_{3}$ - are worrisome as nitrate nitrogen could be converted into nitrous oxide $\left(\mathrm{N}_{2} \mathrm{O}\right)$, which could increase the atmospheric green house ( $\mathrm{GHG}$ ). $\mathrm{NO}_{3}$ - could also be converted to nitrogen dioxide $\left(\mathrm{NO}_{2}\right)$ and nitrogen gas $\left(\mathrm{N}_{2}\right)$ under waterlogged condition.

\section{Conclusion and Recommendation}

The study was to assess the seasonal variation in nitrogen distribution at a municipal dumpsite following the different landscape positions. The soils at the study location were loamy sand in texture with mean $\mathrm{pH}$ values of 4.50 and 5.00 for the control, and $5.9-7.47$ and $5.80-7.30$ (dumpsite) for both dry and wet seasons. Total nitrogen from the study site were rated low for both seasons, with values for the dry season being slightly higher than the wet season. $\mathrm{NH}_{4}+$ was equally low with means of both seasons varying with a coefficient of $0.06 \%, 0.03 \%, 0.04 \%, 0.2 \%, 0.2 \%$ and $0.09 \%$ for the control, summit crest, shoulder slope, toe slope, interfluve slope and valley floor toposequeces accordingly.

The $\mathrm{NH}_{4}+$ values were slightly higher in the wet than in dry season with the shoulder and toe slopes recording the highest concentration. Values obtained for No2- from the control plot were within the ranges of $2.78-3.20$ and $3.22-3.62 \mathrm{mg} / \mathrm{kg}$ while $2.49-3.45$ and $2.98-3.22 \mathrm{mg} / \mathrm{kg}$ was documented for the shoulder, the toe slope contained between $2.30-2.75$ and $2.70-2.82 \mathrm{mg} / \mathrm{kg}$, the inter fluve slope had similar ranges of $2.32-2.90$ and $2.70-3.08 \mathrm{mg} / \mathrm{kg}$, and the valley floor $2.45-2.60$ and $2.78-2.98 \mathrm{mg} / \mathrm{kg}$ for the dry and wet seasons in the given order.

Nitrate ( $\left.\mathrm{NO}_{3-}\right)$ nitrogen was excessively high across the dumpsite for both seasons with values greater than $48.79 \mathrm{mg} / \mathrm{kg}$; in dry season and > $50.26 \mathrm{mg} / \mathrm{kg}$ in the wet season. The excessive $\mathrm{NO}_{3}-$ could be leached down the profile or washed off with eroded soil particles. $\mathrm{NO}_{3}$ - could equally be converted to nitrous oxide $\left(\mathrm{N}_{2} \mathrm{O}\right)$, a green house (GHG) that could increase the atmospheric content. It is observed that seasonal variation did not significantly affect the $\mathrm{N}$ content at the different landscape positions of the municipal dumpsite in Calabar. It is highly recommended that municipal waste be sorted at source and the organic component composted to harness the rich $\mathrm{N}$ content.

\section{References}

Ågren GI, Wetterstedt JAM. 2007. What determines the temperature response of soil organic matter decomposition? Soil Biology \& Biochemistry 39: 1794-1798.

Morris, S.J. and Boerner, R.E.J. (1998). Landscape patterns of nitrogen mineralization and nitrification in southern Ohio hardwood forests. Landscape Ecology, 13: 215-224.

Akpan-Idiok, A. U. (2012).Physicochemical Properties, Degradation Rate and Vulnerability Potential of Soils Formed on Coastal Plain Sands in Southeast, Nigeria. International Journal of Agricultural Research, 7: 358366.

Asomani-Boateng, R., and M. Haight. 1999. Assessment of municipal solid waste management practices in Accra, Ghana. Journal of Environmental Systems 26 (2): 41-55.

Bationo A, Mokwunye U, Vlek PLG, Koala S, Shapiro BI and Yamoah C 2003. Soil fertility management for sustainable land use in the West African Sudano-Sahelian zone. In: Gichuru MP, Bationo A, Bekunda MA, Goma PC, Mafongoya PL, Mugendi DN, Murwira HM, Nandwa SM, Nyathi P and Swift MJ (Eds.). Soil fertility management in Africa: a regional perspective. TSBF-CIAT. 2003. 
Chu H, Grogan P. (2010). Soil microbial biomass, nutrient availability and nitrogen mineralization potential among vegetation-types in a low arctic tundra landscape. Plant Soil, 329: 411-420. doi: 10.1007/s11104-0o90167-y.

Deng, Y., and Englehardt J.DElectrochemical oxidation for landfill leachate treatment. Waste Management, 27 (3) (2007), pp. 380-388 https://doi.org/10.1016/j.wasman.2006.02.004.

Ediene, VF., Iren OB. and M. M. Idiong (2016). Effects of abattoir effluent on the physicochemical properties of surrounding soils in Calabar Metropolis. International Journal of Advanced Research, 4 (8): 37 - 41.

Hagerty, D. J., J. L. Pavoni and J. E. Heer Jr. 1973. Solid Waste Management Van Nostrand Reinhold, New York FAN (Federal Airport Authority of Nigeria) (2018). Meteorological data. Unpublished, Calabar, Nigeria

Ferrari, J.B. 1999. Fine-scale patterns of leaf litterfall and nitrogen Reproduced from Soil Science Society of America Journal. Published by Soil Science Society of America. All copyrights reserved. cycling in an oldgrowth forest. Canadian Journal of Forest Research. 29:291-302. ISSN 00455067

Hirobe, M., Tokuchi, N., Wachrinrat, C. et al.Fire history influences on the spatial heterogeneity of soil nitrogen transformations in three adjacent stands in a dry tropical forest in Thailand. Plant and Soil 249, 309-318 (2003). https://doi.org/10.1023/A:1022804326662

Kelley, K.R., Stevenson, F.J. Forms and nature of organic N in soil. Fertilizer Research 42, 1-11 (1995). https://doi.org/10.1007/BFoo750495

Krivtsov, V., Griffiths, B. S., Liddell, K., Garside, A., Salmond, R., Bezginova, T., \& Thompson, J. A. (2011). Soil nitrogen availability is reflected in the bacterial pathway. Pedosphere, 21(1), 26-30. https://doi.org/10.1016/S1002-016o(10)60075-6

Kurniawan TA, Lo W, Chan G (2006) Physico-chemical treatments for removal of recalcitrant contaminants from landfill leachate. Journal of Hazard Mater 129:80-10o.https://doi.org/10.1016/j.jhazmat.2005.08.010

Landon, J. R. (1991). Booker tropical soil manual: Hand book on soil survey and agricultural land evaluation in the tropic and sub - tropics. Edinburgh, and Booker Tate limited.

Marx, D., Tuckerman, M., Hutter, J. et al. The nature of the hydrated excess proton in water. Nature 397, 601-604 (1999). https://doi.org/10.1038/17579

Miller, R.W. and R.L. Donahue, 1995. Soils in our Environment. 7th Edn., Prentice Hall Inc., India.

Pavoni, J. L., J. E. Heer Jr. and D. L. Hagerty. 1975. Handbook of Solid Waste Disposal, Materials and Energy Recovery. Van Nostrand Reinhold Company, New York.

Öquist MG, Sparrman T, Klemedtsson L, Drotz SH, Grip H, Schleucher J, et al. Water availability controls microbial temperature responses in frozen soil CO2 production. Glob Chang Biol. 2009;15: 2715-2722. doi: 10.1111/j.1365-2486.2009.01898.x.

Paul, E. A., and Clark, F. E., 1989. Soil Microbiology and Biochemistry. New York: Academic Press, 273 pp. Google Scholar

Schulten, H.-R., and Schnitzer, M.. 1997. Chemical model structures for soil organic matter and soils. Soil Sci. 162: 115-130. doi: https://doi.org/10.1097/ooo10694-199702000-00005

Schimel JP, Bennett J (2004) Nitrogen mineralization: challenges of a changing paradigm. Ecology 85:591-602 doi:10.1890/03-8002

Udo E. J., Ibia, T. O., Ogunwale, J. A., Ano, A. O. \& Esu, I. E (2009). Manual of Soil, Plant and Water Analyses. Lagos: Sibon Books. 2 - 12. 